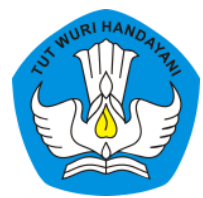

Page: 59-74

\title{
Pengembangan Video Pembelajaran 3S untuk Mendongkrak Self Efficacy Siswa dalam Mengambil Keputusan Study Lanjut di Era Revolusi Industri 4.0
}

\author{
Yang Gustida Aditya Jakti \\ UPT Sekolah Menengah Pertama Negeri 2 Kota Mojokerto, Jawa Timur \\ Contributor Email: ygustida@gmail.com
}

\begin{abstract}
Article Url: http:/ / ojsdikdas.kemdikbud.go.id/index.php/didaktika/article/view/127
\end{abstract}
Published: Mar 30, 2020

\begin{abstract}
The tricky problem in realizing national education goals in the era of the industrial revolution 4.0 related to specialization in junior high is the low self-efficacy of students in making further study decisions. The problem is related to the challenges of development and future goals of students. Based on experience during teaching, observation, and question and answer with 9th grade students, accepting students answer doubts in determining secondary school. Students take friends or pursue achievements without seeing their condition. This Innovative work is about video learning $3 S$ (school, senior, support) which become a real solution to address the conflicts that occur in 9th grade students associated with low self-efficacy in making further study decisions. The development of this innovative work is of Research and Development (RED) type by applying the ADDIE model. The $3 S$ instructional video media (school, seniors, support) applied to 92 students in learning activities resulted in several studies. Based on data analysis, self efficacy and the ability to make decisions further increase heterogeneity. The percentage increase in self-efficacy increased varied, class 9F showed an increase of $5 \%$, class $9 \mathrm{G}$ only increased by $1 \%$ and class $9 \mathrm{I}$ increased by $5 \%$. The percentage of decision making towards further improvement, class 9F increased by 1\%, class 9G increased by $2 \%$, and class 9I only increased by $0.5 \%$. However, students show high enthusiasm, are more serious and focused throughout the learning process. Students receive information as well as understanding more related to advanced studios after seeing $3 S$ learning videos (school, seniors, support). Based on the data that has been obtained, it can be concluded that the $3 S$ learning video (school, senior, support) is able to boost students' self efficacy in making further study decisions.
\end{abstract}

Keywords: Learning Videos; Self-efficacy; Decision-making; Frther Study 


\begin{abstract}
Abstrak
Permasalahan pelik dalam merealisasikan tujuan pendidikan nasional di era revolusi industri 4.0 terkait peminatan di SMP adalah rendahnya self efficacy siswa dalam mengambil keputusan studi lanjut. Masalah tersebut berpotensi menghambat tugas perkembangan dan tujuan masa depan siswa. Berdasarkan pengalaman selama mengajar, observasi, dan tanya jawab dengan siswa kelas 9, mayoritas siswa mengalami keraguan dalam menentukan sekolah lanjutan. Siswa cenderung mengikuti teman atau sekedar mengejar prestige tanpa melihat kondisi diri. Karya inovasi berupa media video pembelajaran 3S (school, senior, support) merupakan solusi nyata untuk menyikapi permasalahan yang terjadi pada siswa kelas 9 terkait rendahnya self efficacy dalam mengambil keputusan studi lanjut. Pengembangan karya inovasi ini berjenis Research and Development (RED) dengan menerapkan model ADDIE. Media video pembelajaran $3 S$ (school, senior, support) yang diterapkan pada 92 siswa dalam kegiatan pembelajaran menghasilkan beberapa data penelitian. Berdasarkan analisis data, self efficacy dan kemampuan mengambil keputusan studi lanjut mengalami peningkatan yang heterogen. Prosentase peningkatan Self efficacy cenderung beragam, kelas 9F menunjukkan peningkatan 5\%, kelas 9G hanya meningkat 1\% dan kelas 9I meningkat 5\%. Prosentase pengambilan keputusan terhadap studi lanjut juga mengalami peningkatan beragam, kelas 9F meningkat 1\%, kelas 9G meningkat 2\%, dan kelas 9I hanya meningkat 0,5\%. Namun demikian, siswa menunjukkan antusiasme tinggi, lebih serius dan fokus selama proses belajar berlangsung. Siswa mengaku mendapat informasi serta pemahaman yang lebih baik terkait studi lanjut setelah melihat video pembelajaran $3 S$ (school, senior, support). Berdasarkan data yang telah diperoleh, dapat disimpulkan bahwa video pembelajaran 3S (school, senior, support) mampu mendongkrak self efficacy siswa dalam mengambil keputusan studi lanjut.
\end{abstract}

Kata Kunci: Video Pembelajaran; Self Efficacy; Pengambilan Keputusan; Studi Lanjut

\title{
A. Pendahuluan
}

Perkembangan arus global yang masif serta serta semakin mendekatnya era revolusi industri 4.0 ke berbagai sektor kehidupan menuntut seluruh komponen pendidikan untuk berinovasi. Ungkapan tersebut sesuai dengan paparan WANTIKNAS pada acara Making Indonesia 4.0 Conference di Kemenperin RI tanggal 24 Oktober 2018 yang menyatakan bahwa "dunia kini memasuki era revolusi industri 4.0, yakni industri berdasarkan cyber-pyhsical yang menekankan pada pola digital economy, artificial intelligence, big data, robotic ,dan lain sebagainya atau dikenal dengan fenomena disruptive innovation" (Habibie, 2018: 7). 
Mengacu kepada realita yang ada, karakter kepribadian siswa $\mathrm{SMP} /$ Mts yang masih labil dituntut untuk mengambil keputusan terkait studi lanjut. Secara tidak langsung, kondisi tersebut membuat mayoritas siswa kurang yakin terhadap kemampuannya dalam menentukan masa depan. Pada dasarnya mereka tahu pentingnya peminatan studi lanjut, namun demikian sebagian besar belum yakin akan kemampuannya untuk menjalani atau menentukan studi lanjut yang tepat. Kondisi kurang yakin terhadap kemampuan diri dalam menentukan studi lanjut sesungguhnya merupakan suatu kondisi yang menggambarkan rendahnya keyakinan terhadap kemampuan diri.

Berdasarkan pengalaman selama mengajar, observasi, dan wawancara, mayoritas siswa mengalami keraguan ketika diberi pertanyaan studi lanjut. Kondisi tersebut menggambarkan rendahnya kemampuan dalam menentukan keyakinan terhadap sekolah lanjut sehingga siswa cenderung mengikuti teman atau sekedar mengejar prestige sekolah tanpa melihat kemampuan.

Keyakinan terhadap kemampuan diri tersebut disebut self efficacy. Menurut Bandura (dalam Feist \& Feist, 2010: 212), self efficacy merupakan suatu keyakinan individu terhadap kemampuan yang dimiliki untuk mengatur fungsi diri pribadi dan peristiwa dalam lingkungan. Lebih lanjut, Baron dan Byrne (dalam Ghufron \& Risnawati, 2010: 74) menyatakan self efficacy merupakan suatu pertimbangan yang dilakukan seseorang terkait kemampuan atau kompetensi diri untuk melakukan tugas, mencapai tujuan, serta mengatasi hambatan.

Mengacu kepada pemahaman tersebut, maka self efficacy atau efikasi diri merupakan suatu kondisi keyakinan individu terhadap kemampuan serta kompetensi yang dimiliki untuk melaksanakan tugas, mencapai tujuan dan mengatasi hambatan.

Menurut Sondang P. Siagian (2013: 24), “pengambilan keputusan merupakan suatu pendekatan yang sistematis terhadap hakikat alternatif yang dihadapi dan mengambil tindakan yang menurut perhitungan merupakan tindakan yang paling cepat". Lebih lanjut, George R. Terry 
(dalam Syamsi, 2007: 5) menyatakan bahwa pengambilan keputusan adalah "pemilihan alternatif perilaku (kelakuan) tertentu dari dua atau lebih alternatif yang ada".

Berdasarkan pengertian tersebut, dapat disimpulkan bahwa pengambilan keputusan merupakan suatu proses yang sistematis terkait beberapa alternatif tindakan yang dihadapi dan diambil suatu tindakan terbaik guna meraih alternatif yang paling efektif dan efisien.

Mengacu kepada permasalahan yang telah dijabarkan, dapat disimpulkan bahwa rendahnya self efficacy siswa kelas 9 dalam mengambil keputusan studi lanjut perlu disikapi dengan serius, efektif dan efisien. Selain itu, permasalahan tersebut memerlukan langkah nyata serta solusi yang tepat sehingga pengambilan keputusan menentukan sekolah lanjutan dapat dilakukan dengan baik.

Salah satu cara mengatasi hambatan tersebut adalah melalui penggunaan media pembelajaran yang tepat. Media yang dipergunakan seyogyanya harus menarik, mengikuti perkembangan era revolusi industri 4.0 dan mampu meningkatkan self efficacy siswa baik secara langsung maupun bertahap. Hal tersebut dilakukan karena media pembelajaran merupakan suatu alat bantu mengajar yang turut mempengaruhi iklim, kondisi, dan lingkungan belajar yang ditata dan diciptakan guru (Arsyad, 2014: 19).

Media yang digunakan mengarah kepada video pembelajaran. Lebih tepatnya video pembelajaran 3S. Konsep 3S tersebut merupakan singkatan dari school, senior, support. Hal tersebut dilakukan agar lebih mudah diingat dan menarik Secara garis besar, video pembelajaran 35 menggambarkan kondisi SMA/SMK/MA (school), siswa yang belajar di SMA/SMK/MA (senior) dan kalimat dukungan siswa agar yakin menentukan sekolah lanjutan (support).

Menurut Munir (2012: 289), video merupakan "suatu teknologi penangkapan, perekaman, pengolahan, dan penyimpanan, pemindahan, dan perekonstruksian urutan gambar diam dengan menyajikan adeganadegan dalam gerak secara elektronik". Menurut Kamus Besar Bahasa 
Indonesia (Depdiknas P. B., 2008: 1261), video merupakan "rekaman gambar hidup atau program televisi untuk ditayangkan lewat pesawat televisi".

Pemahaman terkait 3S lebih mengarah kepada school, senior, support. School mengarah kepada konsep sekolah yang menurut Kamus Besar Bahasa Indonesia merupakan "bangunan atau lembaga untuk belajar dan mengajar serta tempat menerima dan memberi pelajaran" (Depdiknas P. B., 2008: 1013). Untuk Senior disesuaikan dengan konsep senior atau kakak kelas yang berarti lebih tinggi dalam tingkat kelas atau matang secara pengalaman dan kemampuan (Depdiknas P. B., 2008: 1038). Sedangkan Support lebih mengarah kepada dukungan yang dapat diartikan sebagai "bantuan atau sokongan" (Depdiknas P. B., 2008: 279). Berdasarkan berbagai pengertian tersebut, dapat disimpulkan bahwa 35 menggambarkan sekolah SMA/SMK/MA, kondisi kakak kelas di SMA/SMK/MA, dan dukungan yang berupa kalimat untuk memotivasi siswa agar yakin dan pantang menyerah dalam melanjutkan studi.

Berdasarkan berbagai pengertian tersebut, dapat disimpulkan bahwa media video pembelajaran 35 merupakan suatu alat (sarana) yang berbentuk rekaman gambar terkait situasi kondisi sekolah lanjutan (SMA/SMK/MA) baik dari segi sarana, prasarana, dan proses KBM yang didukung kalimat motivasi serta diproses sedemikian rupa sehingga mampu merangsang pikiran, perhatian, perasaan, dan minat siswa dalam menentukan studi lanjut.

Penelitian relevan yang digunakan dalam penelitian ini mengacu kepada beberapa hasil penelitian Widyastuti dan Pratiwi (2013: 237) yang menyatakan bahwa semakin tinggi self efficacy, maka semakin tinggi kemantapan dalam pengambilan keputusan karir siswa, begitu juga sebaliknya. Selain itu, self efficacy berkontribusi terhadap kemantapan pengambilan keputusan karir sebesar 30,8\%.

Hasil penelitian berikutnya dikemukakan oleh Fadhli (2015: 29) yang menyatakan bahwa penggunaan media video dalam pembelajaran 
IPS mampu meningkatkan prestasi belajar dibandingkan yang menggunakan media buku bergambar.

Adapun rumusan masalah penelitian ini mengarah kepada apakah pengembangan video pembelajaran $3 S$ untuk mendongkrak self efficacy siswa dalam mengambil keputusan studi lanjut dapat dilakukan dan bagaimana hasilnya.

Karya inovasi media video pembelajaran 35 pada dasarnya merupakan media pembelajaran yang terfokus kepada penerapan video untuk mendongkrak self efficacy siswa. Tujuan akhir media ini diharapkan mampu membantu siswa dalam memperbaiki pemahaman diri serta pengambilan keputusan terkait studi lanjut. Hasil media video pembelajaran 3S diharapkan mampu meningkatkan self efficacy siswa dalam mengambil keputusan studi lanjut.

\section{B. Metode}

Rancangan/desain penelitian Research and Development (R\&D) model ADDIE. Pemilihan model ADDIE dikarenakan model ADDIE cukup sederhana dan sistematik. Hal tersebut sesuai dengan pendapat Pribadi (2014: 22-23) yang menyatakan bahwa “ADDIE merupakan model desain sistem pembelajaran yang sederhana dan sistematik yang dapat diterapkan untuk mendesain atau mengembangkan pelatihan secara efektif dan efisien".

Lebih lanjut, Pribadi (2014: 23) menyatakan bahwa "model ADDIE memiliki 5 tahapan yang terdiri dari analysis, design, development, implementation dan evaluation."

Subyek penelitian ini adalah siswa kelas 9F, 9G, 9H dan 9I dengan jumlah total 122 siswa. Akan tetapi, kelas 9H digunakan sebagai kelas uji validitas reliabilitas angket dan uji coba media. Penelitian dilaksanakan dalam dua tahap. Tahap pertama terkait pengambilan data media dan tahap kedua terkait pengambilan data uji coba. Lokasi pengambilan data 
dalam rangka membuat media dilakukan di SMA Negeri 1, 2, 3 Kota Mojokerto, SMK Negeri 1, 2 Kota Mojokerto dan MAN Kota Mojokerto.

Proses penyusunan media dilakukan kurang lebih 4 bulan, dimulai dari penyusunan skenario pada bulan September dan berakhir pada bulan Desember. Untuk pengambilan data uji coba dilakukan pada bulan Januari dan Pebruari.

Teknik pengumpulan data pada penelitian ini menggunakan instrumen angket. Adapun angket yang digunakan mengarah kepada instrumen The General Self-Efficacy Scale (GSE) yang dikembangkan oleh Aristi Born, Ralf Schwarzer dan Matthias Jerusalem tahun 1995, instrumen pengambilan keputusan studi lanjut dan instrumen persepsi siswa. Data yang telah terkumpul selanjutnya dianalisis secara deskriptif kuantitatif.

Video 3S (school, senior, support) menggambarkan situasi dan kondisi SMA, SMK dan MA. Sekolah yang digunakan sebagai model video adalah sekolah negeri setingkat SMA yang terdapat di Kota Mojokerto. Video ini dibuat secara terencana dengan menggunakan berbagai perangkat seperti video camera, ponsel, aplikasi adobe premiere pro CC 2014, laptop. Dalam video ini terangkum beberapa poin penting, diantaranya adalah gambaran nyata situasi dan kondisi sekolah, proses pendidikan baik di dalam maupun luar kelas, kondisi belajar mengajar serta fasilitas yang menunjang keberhasilan pendidikan di lingkup SMA/SMK/MA.

Video 35 (school, senior, support) dibuat dalam format MP4 sehingga dapat diputar berbagai video player. Namun demikian, agar lebih mudah diakses berbagai pihak khususnya dalam bidang pendidikan, video 35 diupload di media online youtube.com. Pemilihan media online dikarenakan kebiasaan masyarakat luas termasuk siswa saat ini lebih menyukai streaming di youtube dibandingkan melihat acara televisi. Selain itu, video $3 S$ (school, senior, support) tersebut juga 
dipadupadankan dengan musik dan transisi gambar yang dinamis serta menyenangkan sehingga terkesan mampu meningkatkan motivasi.

Video pembelajaran 3S (school, senior, support) merupakan media audio visual yang dirancang dengan memperhatikan kriteria pemilihan media, diantaranya:

1. Sesuai dengan tujuan pembelajaran

2. Praktis, luwes, dan bertahan

3. Guru mampu dan terampil menggunakan media tersebut

4. Sesuai dengan keadaan siswa

5. Ketersediaan media atau alat pembuat media

Langkah pembuatan video pembelajaran 3S (school, senior, support) setelah alat dan bahan terpenuhi adalah sebagai berikut.

a) Buat skenario yang ingin diwujudkan dalam video.

b) Siapkan alat/devices yang digunakan untuk mengambil video dan foto.

c) Ambil objek secara langsung di lapangan sesuai dengan skenario dan kebutuhan yang diinginkan terkait hasil akhir video. Pengambilan video dilakukan di SMA, SMK dan MA Negeri yang ada di Kota Mojokerto.

d) Kumpulkan berbagai data video, foto dan musik yang diperoleh, kemudian di edit menggunakan software aplikasi Adobe Premiere Pro CC 2014.

e) Menguji file video yang sudah jadi melalui aplikasi pemutar video seperti GOM Player, VLC Media Player, KMPlayer, Windows Media Player, dsb.

f) Mengupload video di channel youtube.

\section{Hasil dan Pembahasan}

Data hasil penelitian diperoleh setelah sebelumnya dilakukan uji validitas dan reliabilitas menggunakan SPSS 25. Adapun data yang 
diperoleh terdiri dari 3 hal, yakni data self efficacy, pengambilan keputusan, dan persepsi siswa terhadap media. Data perolehan disajikan sebagai berikut.

\section{Tabel 1: Prosentase Data Persepsi Siswa Terhadap Media Video Pembelajaran $3 S$}

\begin{tabular}{|c|c|c|c|c|}
\hline \multirow[b]{2}{*}{$\begin{array}{l}\text { No } \\
\text {. }\end{array}$} & \multicolumn{4}{|c|}{ Nilai } \\
\hline & Aspek & $\begin{array}{c}\text { Total } \\
\text { Peroleha } \\
\text { n }\end{array}$ & Maks. & $\%$ \\
\hline 1. & Penyajian & 662 & 736 & 90 \\
\hline 2. & $\begin{array}{l}\text { Efek dalam } \\
\text { Pembelajaran }\end{array}$ & 1596 & 1840 & 87 \\
\hline 3. & $\begin{array}{l}\text { Tampilan } \\
\text { Keseluruhan }\end{array}$ & 930 & 1104 & 84 \\
\hline
\end{tabular}

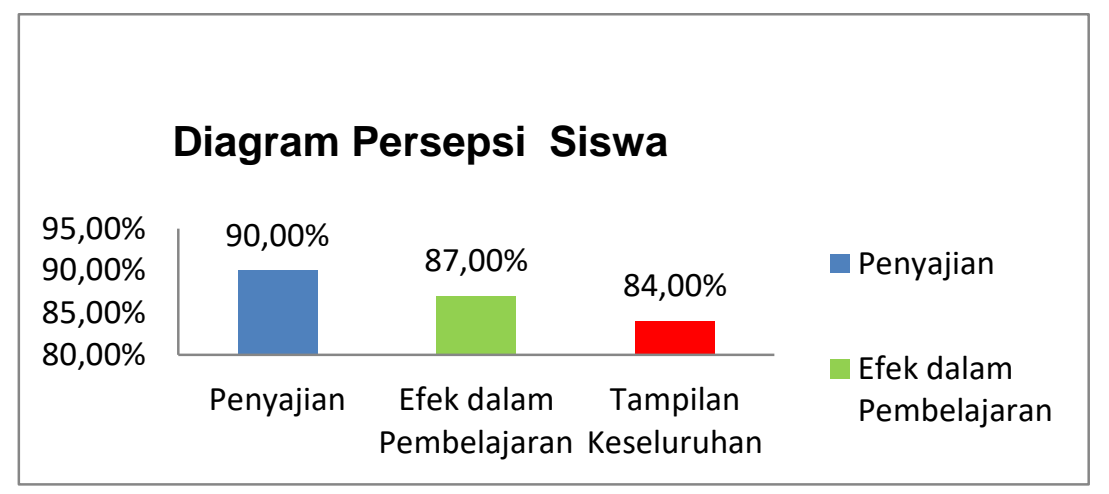

(Sumber: data primer yang diolah)

Berdasarkan data tersebut, video pembelajaran $3 S$ dinilai sangat baik dalam membantu siswa mengerti dan memahami studi lanjut. Selama kegiatan, siswa sangat antusias, serius, fokus dan terjadi diskusi secara aktif. Siswa mengaku mendapat banyak informasi serta pemahaman yang lebih baik. Selain itu, banyak siswa yang datang secara sukarela untuk konseling dalam rangka membahas studi lanjut. 
Hasil penelitian ini mendukung pernyataan yang dikemukakan oleh Fadhli (2015: 29) yang menyatakan bahwa penggunaan media video dalam pembelajaran IPS mampu meningkatkan prestasi belajar dibandingkan yang menggunakan media buku bergambar. Meskipun prestasi belajar dan perubahan perilaku berbeda, tetapi dapat disimpulkan bahwa media video mampu meningkatkan berbagai jenis prestasi siswa.

Data Pre Test-Post Test Self Efficacy dan Pengambilan Keputusan Studi Lanjut (Sumber: data primer yang diolah)

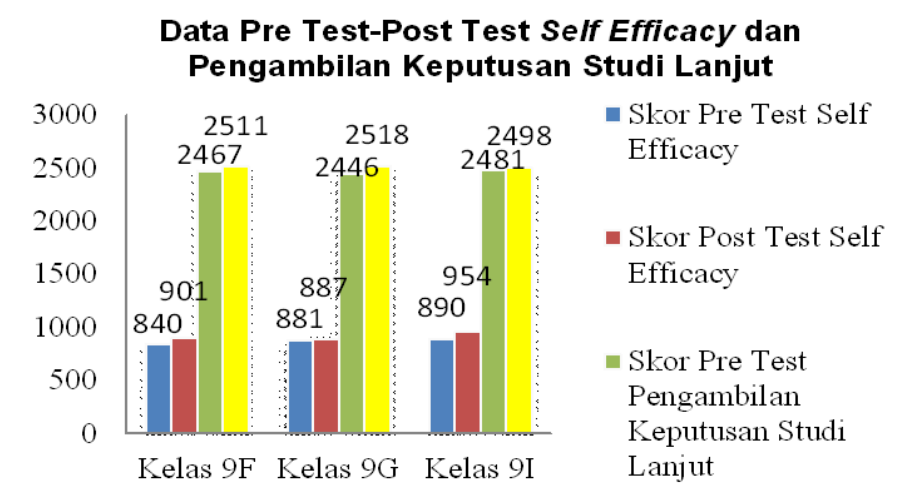

Mengacu kepada berbagai data tersebut, peningkatan self efficacy dan pengambilan keputusan studi lanjut antara sebelum dan sesudah penggunaan media video pembelajaran $3 S$ memang berbeda antar kelas serta memiliki hasil yang tidak terlalu signifikan. Akan tetapi, prosentase perolehan siswa menunjukkan hasil diatas $70 \%$ sehingga hal tersebut menunjukkan bahwa penggunaan media video pembelajaran $3 S$ terbukti memiliki dampak yang cukup positif khususnya dalam materi studi lanjut Bimbingan dan Konseling.

Berdasarkan data self efficacy, siswa kelas 9F terlihat meningkat sebesar 61 poin dari 840 menjadi 901 dengan rerata prosentase meningkat $5 \%$ dari $70 \%$ menjadi $75 \%$. Untuk siswa kelas 9G terlihat meningkat walaupun tidak setinggi siswa kelas 9F yakni hanya sebesar 6 poin dari skor 881 menjadi 887 dengan peningkatan rerata prosentase hanya 1\% 
yakni dari dari $70 \%$ menjadi $75 \%$. Data siswa kelas 9I menunjukkan peningkatan sebesar 64 poin dari skor 890 menjadi 954 dengan rerata prosentase meningkat sebesar $5 \%$ dari $72 \%$ menjadi $77 \%$.

Data tabel dan diagram pengambilan keputusan studi lanjut siswa memiliki hasil yang sejalan dengan data self efficacy. Data tersebut menunjukkan bahwa kemampuan pengambilan keputusan studi lanjut mengalami peningkatan setelah diberikan media video pembelajaran 3S. Skor perolehan kelas 9F menunjukkan peningkatan sebesar 44 poin dari 2467 menjadi 2511 dengan peningkatan rerata prosentase hanya 1\% dari 79\% menjadi $80 \%$. Untuk kelas $9 \mathrm{G}$ menunjukkan peningkatan sebesar 72 poin dari 2446 menjadi 2518 dengan peningkatan rerata prosentase $2 \%$ dari $76 \%$ menjadi 78\%. Lebih lanjut, data pengambilan keputusan kelas 9I menunjukkan peningkatan hanya 17 poin dari 2481 menjadi 2498 dengan peningkatan rerata prosentase yang hanya $0,5 \%$ yakni dari $77 \%$ menjadi $77,5 \%$.

Mengacu kepada data tersebut, meningkatnya self efficacy ternyata mampu mempengaruhi peningkatan kemampuan siswa dalam mengambil keputusan terkait studi lanjut. Dengan demikian, dapat disimpulkan bahwa peningkatan self efficacy siswa berbanding lurus dengan peningkatan kemampuan pengambilan keputusan studi lanjut. Hasil ini sesuai dengan pendapat Widyastuti dan Pratiwi (2013: 237) yang menyatakan bahwa semakin tinggi self efficacy, maka semakin tinggi kemantapan dalam pengambilan keputusan karir siswa, begitu juga sebaliknya. Selain itu, self efficacy berkontribusi terhadap kemantapan pengambilan keputusan karir sebesar 30,8\%.

Berdasarkan data tersebut, dapat disimpulkan bahwa penggunaan media video pembelajaran $3 S$ mampu meningkatkan self efficacy serta mendorong siswa untuk menentukan keputusan yang terbaik terkait studi lanjut. Dengan demikian, media video pembelajaran $3 S$ secara tidak langsung telah memotivasi, mengubah persepsi dan tingkah laku siswa. 
Dengan adanya motivasi dan keinginan untuk berubah dan sukses, maka keyakinan, kemantaban dan keinginan siswa untuk melanjutkan studi ke jenjang yang lebih tinggi menjadi lebih kuat. Hasil ini sejalan dengan pendapat Purwanti (2015: 47) yang menunjukkan bahwa pengembangan video pembelajaran mampu mengefektifkan pembelajaran serta meningkatkan motivasi siswa.

\section{Penutup}

\section{Kesimpulan}

Self efficacy dan pengambilan keputusan terhadap studi lanjut siswa kelas 9F, 9G dan 9I mengalami peningkatan setelah diberikan kegiatan dengan menggunakan media video pembelajaran. Prosentase peningkatan Self efficacy cenderung beragam, untuk siswa kelas 9F mengalami peningkatan sebesar 5\%. Untuk siswa kelas 9G mengalami peningkatan walaupun hanya sebesar 1\% sedangkan siswa kelas 9I menunjukkan peningkatan yang sama dengan kelas 9F yakni sebesar 5\%. Lebih lanjut, kemampuan siswa dalam pengambilan keputusan studi lanjut memiliki hasil yang sejalan dengan self efficacy. Kemampuan pengambilan keputusan studi lanjut siswa kelas 9F menunjukkan peningkatan meskipun hanya $1 \%$. Untuk siswa kelas 9G menunjukkan peningkatan sebesar $2 \%$ dan siswa kelas 9I menunjukkan peningkatan hanya $0,5 \%$.

Selama proses pelayanan, siswa terlihat sangat antusias, serius, fokus dan terjadi diskusi secara aktif. Siswa mengaku mendapat banyak informasi serta pemahaman yang lebih baik setelah melihat video tersebut. Setelah kegiatan, banyak siswa yang konseling secara sukarela untuk membahas studi lanjut. Dengan demikian, media video pembelajaran 3S secara tidak langsung telah memotivasi, mengubah persepsi dan tingkah laku siswa sehingga keyakinan, kemantaban dan keinginan siswa untuk melanjutkan studi ke jenjang yang lebih tinggi menjadi lebih kuat. 


\section{Saran}

Berdasarkan hasil penggunaan media video pembelajaran 35 (school, senior, support), maka dapat diberikan saran sebagai berikut;

a. Guru diharapkan dapat menggunakan media video pembelajaran 3S (school, senior, support) sebagai salah satu cara menyampaikan informasi terkait sekolah lanjutan setelah SMP/sederajat;

b. Menggunakan media video pembelajaran 3S (school, senior, support) yang tepat dan prosedural, guru Bimbingan dan Konseling dapat membantu mengatasi permasalahan siswa;

c. Video pembelajaran 3S (school, senior, support) sangat bermanfaat karena dapat menjadikan pembelajaran lebih menarik, efektif, dan efisien;

d. Guru dapat mengembangkan media video pembelajaran 35 (school, senior, support) sesuai dengan situasi dan kondisi siswa, lapangan dan konteks pelajaran yang ingin disampaikan;

e. Guru diharapkan mampu menggunakan dan mengembangkan media video pembelajaran 3S (school, senior, support) agar menjadi lebih baik, menarik, efektif dan efisien;

f. Sekolah kiranya mampu mendukung sarana prasarana dalam menggunakan media pembelajaran khususnya pembelajaran yang menggunakan sarana dan prasarana IT, seperti proyektor, speaker, jaringan wifi, laptop, dan smartphone.

\section{Ucapan Terimakasih}

Terima kasih saya sampaikan kepada Bapak Kepala Sekolah dan teman-teman guru di SMP Negeri 2, Mojokerto, Jawa Timur yang telah memberikan fasilitas dan bantuan, baik waktu maupun tenaga sehingga penelitian ini dapat diselesaikan dengan baik. 


\section{Daftar Referensi}

Arsyad, A. (2014). Media Pembelajaran. Jakarta: PT. Rajagrafindo Persada.

Depdiknas. (2003). Undang-Undang Nomor 20 Tahun 2003, Tentang Sistem Pendidikan Nasional. Jakarta: Depdiknas.

Depdiknas. (2003). Undang-Undang Republik Indonesia Nomor 20 Tahun 2003 Tentang Sistem Pendidikan Nasional. Lembaran Negara Republik Indonesia Nomor 4301.Jakarta: Sekretariat Negara.

Depdiknas, P. B. (2008). Kamus Besar Bahasa Indonesia. Jakarta: Gramedia Pustaka Utama.

Fadhli, M. (2015). "Pengembangan Media Pembelajaran Berbasis Video Kelas Iv Sekolah Dasar". Jurnal Dimensi Pendidikan dan Pembelajaran, III, 24-29.

Feist, J., \& Feist, G. J. (2010). Teori Kepribadian (Buku 2) (Edisi 7). Jakarta: Salemba Humanika.

Ghufron, M. N., \& Risnawati, R. (2010). Teori-teori Psikologi. Jogjakarta: Ar-Ruzz Media.

Habibie, E. I. (2018). Arah Indonesia 4.0. Handout Materi Diskusi No.068/WANTIKNAS/MAT/OKT/2018 acara Making Indonesia 4.0 Conference, 24 Oktober 2018 di Kementerian Perindustrian Republik Indonesia. Jakarta: Tidak diterbitkan.

Kemdikbud. (2018, Agustus 5). https://kbbi.web.id/. Dipetik September 28, 2018, dari https://kbbi.web.id/studi: https://kbbi.web.id/studiM

Kemdikbud. (2018, Agustus 5). https://kbbi.web.id/. Dipetik September 28, 2018, dari https://kbbi.web.id/lanjut: https://kbbi.web.id/lanjut.

Kemendikbud. (2014). Panduan Bimbingan dan Konseling Sekolah Menengah Pertama. Jakarta: Kemendikbud.

Munir. (2012). Multimedia: Konsep \& Aplikasi dalam Pendidikan. Bandung: Alfabeta.

Pribadi, B. A. (2014). Desain dan Pengembangan Program Pelatihan Berbasis Kompetensi. Implementasi Model ADDIE. Jakarta: Prenada Media Group.

Purwanti, B. (2015). Pengembangan Media Video Pembelajaran Matematika. Jurnal Kebijakan dan Pengembangan Pendidikan, III, 42-47. 
Siagian, P. D. (2013). Teori dan Praktek Pengambilan Keputusan. Jakarta: PT Toko Gunung Agung.

Siswanto, R., Sugiono, S., \& Prasojo, L. (2018). The Development of Management Model Program of Vocational School Teacher Partnership with Business World and Industry Word (DUDI). Jurnal Ilmiah Peuradeun, 6(3), 365-384. doi:10.26811/peuradeun.v6i3.322.

Syamsi, I. (2007). Pengambilan Keputusan dan Sistem Informasi. Jakarta: Bumi Aksara.

Widyastuti, R. J., \& Pratiwi, T. I. (2013). "Pengaruh Self Efficacy Dan Dukungan Sosial Keluarga Terhadap Kemantapan Pengambilan Keputusan Karir Siswa". Jurnal BK UNESA, III, 231-238. 
Vol. 4, No. 1, Maret 2020 